Резюме

Машика В.П. Роль защитника в осуществлении представительства в уголовном производстве.

В научной статье рассматривается процессуальный статус адвоката при осуществлении представительства по уголовным производствах. Обращается внимание на защиту прав и законных интересов лиц, являющихся участниками уголовного производства, через механизм представительства адвокатом совершенно разных субъектов уголовного производства (потерпевшего, свидетеля, гражданского истца, гражданского ответчика, подозреваемого, обвиняемого, юридических лиц). Особое внимание уделяется возможностям адвоката в отстаивании интересов клиента в зависимости от ситуации и процессуального статуса.

Ключевые слова: представительство, процессуальный статус, адвокат, защитник, адвокатская деятельность, профессиональная юридическая помощь, уголовное производство.

\title{
Summary
}

Valery Mashyka. The role of the defence counselor in the representation in criminal proceedings.

The article deals with the procedural status of the lawyer during the representation in criminal proceedings. The aspect of protecting rights and legitimate interests of persons involved in criminal proceedings through the mechanism of representation by the lawyer of completely different subjects of criminal proceedings (an aggrieved person, a witness, a civil plaintiff, a civil defendant, a suspect, an accused, an entity) is considered.

It is established that the institution of representation in criminal proceedings ranks high among the current problems of criminal procedure legislation and determines the peculiarities of the procedural status of persons who may represent the interests of the subjects of criminal proceedings. Representatives may enjoy the procedural rights of the persons they represent, except in cases of personal involvement. In criminal proceedings such participants as an aggrieved person, a witness, a suspect, an accused, a civil plaintiff, a civil defendant, a legal entity may have representatives.

The role of each participant in ensuring and respecting rights, freedoms and legitimate interests in criminal proceedings, while receiving professional legal assistance as an instrument of protection, is examined.

The article covers the stage of correct documenting the relations between the defense counsellor and his or her client in criminal proceedings. Documents confirming the authority to represent include: 1) a certificate of the right to practice as a counselor, an order and a contract with a counselor, or an order of a body or an institution authorized by law to provide free legal assistance; 2) a copy of the constituent documents of a legal entity 3 ) a power of attorney. ceedings.

Key words: representation, procedural status, lawyer, defense counselor, advocacy, professional legal assistance, criminal pro-

DOI: 10.36695/2219-5521.2.2019.34

УДК 343.35

А.О. Хлопов

Артем Олександрович Хлопов, аспірант Харківського національного університету внутрішніх справ*

ORCID: 0000-0001-5342-9183

\section{ТЕНДЕНЦІЇ РОЗВИТКУ ЗАКОНОДАВСТВА У СФЕРІ КРИМІНАЛЬНО-ПРАВОВОГО РЕГУЛЮВАННЯ ЗАСТОСУВАННЯ ТА ОБІГУ СПЕЦІАЛЬНИХ ТЕХНІЧНИХ ЗАСОБІВ НЕГЛАСНОГО ОТРИМАННЯ ІНФОРМАЦІї**}

У період трансформаційних процесів, які відбуваються в законодавстві країн світу до яких, зокрема належить і Україна, що адаптує його до країн Європейської спільноти, важливим питанням є забезпечення демократичних та гуманних засад функціонування держави. Правове регулювання поводження із засобами, що можуть таємно фіксувати інформацію про оточуючих, так званих спеціальних технічних засобів отримання інформації (далі - СТЗНОI) є особливо актуальним в умовах науково-технічного прогресу. Необізнаність у технічній складовій призвело до непоміркованих кроків при прийнятті рішень, залишивши свій негативний відбиток на законодавстві України. Особливо це стосується ст. 359 Кримінального кодексу України (далі - КК України), редакція якої декілька разів піддавалася змінам і доповненням. Неузгодженість нормативно-правових актів, поєднання пострадянських та західних підходів у правовому регулюванні позначається на якості закону й правах громадян. У таких умовах слушним видається проведення дослідження розвит-

\section{() А.О. Хлопов, 2019}

* Artem Khlopov, postgradiuate student of Kharkiv National University of Internal Affairs

** Оскільки законодавство у сфері СТЗНОІ в різні часи вдавалося до понять «використання» та «застосування» без їх відокремлення між собою, вважаємо за доцільне, виходячи з особливостей дослідження, оперувати саме терміном «застосування» як загального та технічно більш прийнятного. 
ку нормативно-правового забезпечення в сфері незаконного застосування та обігу СТЗНОI, а також запропонувати напрями вдосконалення законодавства для приведення його у відповідний сучасним соціально-правовим умовам стан.

Серед науковців, які присвятили свої праці окремим питанням нормативно-правового забезпечення у сфері незаконного поводження зі СТЗНОІ, слід звернути увагу на такі прізвища: П.П. Андрушко, В.Я. Бондаренко, С.В. Баринов, В.І. Возний, М.Г. Гапієнко, Б.С. Драп’ятий, М.С. Кривогин, Б.Д. Леонов, І.В. Логінов, М.I. Мельник, Т.В. Лутак, М.М. Мікуліна, О.В. Радченко, М.І. Цимбал та інші. Не зважаючи на поодинокі праці з цього питання, всебічного аналізу стану нормативно-правового забезпечення у сфері CTЗНОI майже не проводилося, що, враховуючи подекуди непослідовну політику з боку держави та поверхове дослідження у супроводі численних змін редакції ст. 359 КК України не дає можливості говорити про задовільний стан справ в окресленій сфері.

Метою статті є всебічний аналіз законодавства у сфері кримінально-правового забезпечення СТЗНОI та тенденцій, що призвели до його змін і доповнень на різних етапах розвитку національного законодавства.

Для досягнення мети були поставлені наступні завдання: 1) проаналізувати процес становлення національного законодавства у сфері СТЗНОІ на різних етапах та дослідити наслідки цих змін; 2) керуючись викладеним матеріалом звернути увагу на найбільш гострі проблеми в правовому регулюванні та запропонувати шляхи їх вирішення.

Відкриття ринків України та перші кроки до ринкової економіки ознаменували потребу врегулювати нові суспільні відносини. Серед них сфера застосування та обігу СТЗНОІ займає особливе місце. Відносно новий, але стрімко прогресуючий напрям суспільних відносин вимагав законодавчого врегулювання у боку держави. 3 цього питання В.I. Возний зазначає, що: «аналіз міжнародного досвіду боротьби із незаконним обігом спецтехніки, врахування європейських стандартів захисту приватності особи, гуманізація відповідальності за правопорушення і врахування результату всесвітнього технологічно-інтелектуального прогресу - основні важелі для модернізації кримінального законодавства» 1 . Прийнята Верховною Радою УРСР 16 липня 1990 р. Декларація «Про державний суверенітет України» проголосила, «необхідність побудови правової держави»², визначивши подальший шлях розвитку правової системи України, декларуючи перевагу загальнолюдських цінностей над класовими та примат міжнародного права ${ }^{3}$.

Національне законодавство у сфері СТЗНОІ характеризується нестабільністю та постійним оновленням, яке ускладнює аналіз існуючих проблем без дослідження всього шляху розвитку правового регулювання у сфері СТЗНОІ з виділенням окремих етапів, кожен з яких має свої особливості та певним чином вплинув правові реалії сьогодення.

Умовно кажучи, розвиток правової системи у сфері СТЗНОІ можна поділити на три великі етапи: перехідний (до 2001 р.); основний (2001-2010рр.) та завершальний (2010-2016 рр.).

Період до 2001 р. можна назвати перехідним з огляду на становлення правової системи незалежної України. У цей час велика частина суспільних відносин продовжувала регулюватися застарілими радянськими приписами, прийняття яких відбувалося в умовах існування залізної завіси та не відповідало ні вимогам часу, ні потребам відтвореної української державності. Перехідний етап тривав до прийняття у 2001 р. нового Кримінального кодексу України та супроводжувався трансформацією національного законодавства, викликавши передумови не тільки удосконаленню вже існуючих галузей права, а й створенню нових. M.I. Цимбал зазначає, що спочатку відносини у сфері СТЗНОІ були визначені доктриною, а згодом і на законодавчому рівні з'явилася кримінальна відповідальність за незаконне поводження зі спецзасобами

Зокрема, одним із перших таких актів був Статуту поштового, телеграфного, телефонного і радіозв'язку $\mathrm{CPCP}^{5}$, де у п. 6 встановлювалося, що зміст усіх видів поштової, телеграфної і радіотелеграфного кореспонденції є таємницею кореспондуючих осіб. Службовцям заборонялося порушувати таємницю спілкування та передавати будь-яким особам відомості отриманих при виконанні службових обов'язків. Порушення вказа-

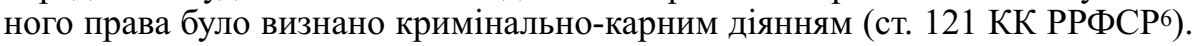

Варто зазначити, що до прийняття 12 червня 1990 р. Основ кримінального судочинства Союзу РСР i союзних республік у кримінальному судочинстві використання доказів, отриманих при застосуванні технічних засобів, було обмеженим. У цьому акті ст. 29 передбачала застосування технічних засобів для виявлення фактичних даних, які можуть використовуватися як докази за умови їх відповідності кримінально-процесуальному законодавства7.

Згодом у 1992 р. Закон України «Про оперативно-розшукову діяльність» визначив порядок здійснення контролю за листуванням, телефонними розмовами, телеграфною та іншою кореспонденцією, а також врегулював питання застосування СТЗНОІ підрозділами уповноваженими на оперативно-розшукову діяльність $^{8}$. Спочатку законодавець врегульовував правовий порядок використання СТЗНОІ з боку держави правоохоронними органами, а вже згодом звернув увагу на приватних осіб, які почали активно використовувати технологічні новинки не тільки в побутових цілях.

У подальшому постанова Верховної Ради України від 17 червня 1992 р. № 2471-ХІІ «Про права власності на окремі види майна» спеціальні технічні засоби негласного отримання інформації стала відносити до тих видів майна, які не можуть перебувати у власності фізичних та юридичних осіб недержавної форми власності. Згідно з постановою такі предмети вилучені з цивільного обороту9. Варто зазначити, що цей підзаконний акт залишається діючим і сьогодні, хоча був прийнятий на виконання ст. ст. 13, 28 і 45 Закону України «Про власність», який уже давно втратив чинність та став історією. Проте досягненням постанови 
є створення основи для подальшого видання Ліцензійною Палатою Служби безпеки України у 1999 р. наказу, який врегулював питання підприємницької діяльності зі СТЗНОІ10.

Фундаментом всієї правової системи стала прийнята у 1996 р. Конституція України. Відповідно до неї кожному громадянину гарантується право на приватність. При цьому не допускаються будь-які дії з конфіденційною інформацією про особу без ії згоди, крім випадків, визначених законом. Цікавою видається ст. 92 Основного Закону, згідно з якою правовий режим власності визначається виключно законами України, що поставило крапку в питанні можливості регулювати режими власності з боку підзаконних актів ${ }^{11}$.

Основний етап (2001-2010рр.) супроводжувався активною роботою законодавця щодо наповнення законодавчої бази, у тому числі нового Кримінального кодексу України 2001 р., до якого внесли ст. 359 «Незаконне використання спеціальних технічних засобів отримання інформації» ${ }^{2}$, чи не вперше в незалежній Україні було офіційно врегульовано відносини у сфері СТЗНОІ на рівні кримінально-правової норми. Законодавець пішов шляхом, згідно з яким вказані засоби є водночас самостійним складом злочину та виступають в якості кваліфікуючої ознаки інших злочинів, наприклад ч. 2 ст. 163 КК України. Такий підхід не має аналогів як серед країн Європейського Союзу, так і серед пострадянських країн, зокрема країн СНД та Грузії. Іншим представником кодифікації законодавства, проведеної на початку нульових років, виступає Цивільний кодекс України (далі - ЦК України), який окреслив питання власності, зокрема у ч. 2 ст. 178 ЦК України визначено, що види об'єктів цивільних прав, перебування яких у цивільному обороті не допускається, мають бути прямо встановлені в законі, а не на рівні підзаконного нормативно-правового акта, тільки підтвердили претензії на можливість подальшої дії цієї постанови ${ }^{13}$. Кодекс не тільки ретранслював положення ст. 92 Конституції України, а й призвів до втрати чинності Закону України «Про власність».

Внесення ст. 359 до КК України потягло оновлення підзаконних актів щодо ліцензування та поводження 3 цими засобами, серед яких: Указ Президента України «Про впорядкування виготовлення, придбання та застосування технічних засобів для зняття інформації з каналів зв'язку», згідно з п. 2 якого на Уряд покладається обов'язок у тримісячний термін затвердити положення про поводження зі СТЗНОI ${ }^{14}$ і спільний наказ Служби безпеки України та Державного комітету України з питань регуляторної політики та підприємництва «Про затвердження порядку...»15, що визначив новий порядок господарської діяльності у означеній сфері.

Завершальний етап (2010-2016 рр.) розпочався прийняттям Закону України «Про внесення змін до Кримінального кодексу України щодо відповідальності за незаконне поводження із спеціальними технічними засобами негласного отримання інформації», який виклав ст. 359 КК України в новій редакції «Незаконні придбання, збут або використання спеціальних технічних засобів отримання інформації», доповнивши словами «придбання та збут»16, що значно розширило спектр кримінально-карних дій.

Однак нова редакція ст. 359 КК України від 2010 р. не стільки вплинула на убезпечення приватного життя людини, скільки призвела до непоодиноких випадків порушення прав власників та ускладнила доступ нових технологій на ринок України. Як зазначає О.Ф. Пасєка: «Запровадження кримінальної відповідальності за незаконне поводження з СТЗНОІ стало логічною спробою законодавця врегулювати важливу сферу, пов'язану з обігом цих засобів. Однак положення ст. 359 КК України, зважаючи на численні зміни ії редакції, викликають радше розчарування, ніж схвалення» ${ }^{17}$. Підтвердження цього слугує пояснювальна записка до законопроекту, яка мотивує необхідність таких змін «незадовільним станом забезпечення в Україні прав людини на недоторканність приватного життя, зокрема, на таємницю листування, телефонних розмов, телеграфної та іншої кореспонденції» ${ }^{18}$. Яке місце відводиться ст. ст. 163 та 182 КК України, що власне і покликані регулюють зазначену сферу, залишилося невідомим.

Окрему увагу заслуговує прийнятий у 2015 р. Закон України «Про внесення змін до деяких законів України щодо розвідувальних органів України» 19 , у ньому рівні закону було врегульовано порядок застосування спецзасобів та надано право виступати замовниками виготовлення органами військового управління розвідки та військовими частинами розвідки Збройних Сил України технічних засобів розвідки і спеціальних технічних засобів. Попри це законодавець не розмежував «технічні засоби розвідки» (далі - ТЗР) та «спеціальні технічні засоби, необхідні для здійснення розвідувальної діяльності» (далі - СТЗНЗРД) між собою. Питання виникають і в тому, яким чином ці засоби співвідносяться зі СТЗНОІ. Допускаємо, що саме для цього законодавець і визначив у назві ст. 359 КК України предмет злочину дещо ширше, де використовує термін «спеціальні технічні засоби отримання інформації», так звані «СТЗ», при цьому оперуючи у диспозиції поняттям СТЗНОІ. Ймовірно, законодавець тільки натякає на похідність всіх цих засобів від СТЗ, що не додає правової визначеності. Узгодження цього питання у межах тієї ж ст. 359 КК України якісно зменшило би помилки при кваліфікації цього злочину.

Чи не останнім витком у розвитку законодавчого регулювання СТЗНОI вважається прийнята у $2016 \mathrm{p}$. постанова Кабінету Міністрів України «Деякі питання...»²0, яка востаннє оновила ліцензійні умови (діючі на сьогодні), визначила критерії належності пристроїв до СТЗНОІ та їх перелік.

Серед основних надбань цієї постанови доволі розширене визначення основних понять, зокрема надана дефініція CTЗНОI, відповідно до якої: спеціальні технічні засоби для зняття інформації з каналів зв'язку та інші технічні засоби негласного отримання інформації - технічні, апаратно-програмні, програмні та інші засоби, які відповідають критеріям належності технічних засобів негласного отримання інформації, що мають технічну забезпеченість для негласного отримання (прийому, обробки, реєстрації та/або передачі) інформації, призначені для використання у скритний спосіб, характерний для оперативно-розшукової, контррозвідувальної або розвідувальної діяльності ${ }^{21}$. Як бачимо, відбулося розширення сфери застосування 
СТЗНОІ, яка охопила контррозвідувальну та розвідувальну діяльність, що узгоджується 3 положеннями Закону України «Про внесення змін до деяких законів України щодо розвідувальних органів України». Втім, окремі питання залишилася поза увагою. Наприклад, невизначеним залишилося поняття «канал зв'язку», а препарати, як СТЗНОІ взагалі були виключені з переліку, що натомість мали місце у попередніх підзаконних актах 3 питань ліцензування таких засобів: у спільному наказі Служби безпеки України та Держкомпідприємництва від 10 жовтня 2006 р. «Про затвердження Ліцензійних умов...» (п.п. 1.2)22 та наказі Служби безпеки України від 31 січня 2011 р. «Про затвердження Ліцензійних умов...» (п.п. 1.6) ${ }^{23}$.

Вказана постанова в сукупності з іншими джерелами мала скласти пазл всієї системи регулювання до купи. Але натомість викликала ситуацію правової невизначеності, де без висновку експерта неможна ідентифікувати, чи дійсно той або інший предмет є СТЗНОІ, навіть за умови наявності переліку та властивостей цих засобів. Щоправда, і в цьому випадку не все так просто, бо нормативною основою таких досліджень виступає «Загальна методика віднесення об'єктів до спеціальних технічних засобів негласного отримання інформації» (зареєстрована в Міністерстві юстиції України 02 березня 2011 р. за № 17.0.01), яка має гриф «для службового використання», а отже, доступ до тексту мають виключно експерти, які проводять дослідження.

Характеризуючи тенденції змін діючого законодавства у сфері поводження зі СТЗНОІ, можна окреслити, що законодавець продовжує перебувати у пошуках моделі прийнятного кримінально-правового регулювання. Підтвердженням цього цього є створює передумови конкурування окремих актів між собою, а періодичне, раз на декілька років, оновлення ліцензійних умов тільки посилює правову невизначеність та протиріччя.

Підбиваючи підсумки вищевикладеного можна констатувати, що на сьогодні в Україні тривають дослідження, спрямовані на комплексне вирішення проблем галузі Кримінального права та сфери незаконного поводження зі СТЗНОІ у тому числі. Аналіз законодавства в окресленій сфері потребує цілісного опрацювання питань про природу цих засобів та їх місце в правовій системі, задля вирішення теоретичних та практичних проблем.

Опрацювання законодавчої бази у рамках цієї наукової праці дає підстави стверджувати, що сфера СТЗНОІ з позиції досягнення високого рівня забезпечення правового регулювання перебуває не в найкращому стані та потребує удосконалення одразу в декількох напрямах. Серед яких, з одного боку, деталізація понятійного апарату та пошуку місця в ньому різних видів СТЗ або їх розмежування, зокрема ТЗР, СТЗНЗРД із послідуючим наданням зрозумілих дефініцій як учасникам у справі, так і пересічним громадянам із залученням експертів у виняткових випадках; $з$ другого - удосконалення вже діючих актів 3 питань ліцензування, обігу та власності на ці засоби. Проведена поетапна характеристика виявляє застарілі, проте діючих, а інколи й конкуруючі між собою документи, що створює запит на перевірку їх відповідності сучасним реаліям та правовим актам вищого рівня.

1 Возний B.I. Генеза законодавства про відповідальність у сфері спеціальних технічних засобів негласного отримання інформації. Modern directions of theoretical and applied researches 2013. SWorld - 19-30 March 2013. URL: http://www.sworld.com. ua/index.php/ru/conference/the-content-of-conferences/archives-of-individual-conferences/march-2013

2 Декларація про державний суверенітет від 16 липня 1990 р. № 55-XII. Відомості Верховної Ради УРСР. 1990. № 31. Ст. 429. URL: https://zakon.rada.gov.ua/laws/show/55-12

3 Тимченко Л.Д. Міжнародне право : підручник. Київ : Знання, 2012. С. 122.

4 Цимбал М.І. Іноземний досвід кримінально-правової протидії незаконного поводження із спеціальними технічними засобами негласного отримання інформації. Науковий вісник Академії муніципального управління. Серія «Право». 2011. С. 232.

5 Устав почтовой, телеграфной, телефонной и радиосвязи Союза ССР. Постановление Совета Народных комиссаров $\mathrm{CCСР} \mathrm{«О} \mathrm{введении} \mathrm{в} \mathrm{действие} \mathrm{Устава} \mathrm{почтовой,} \mathrm{телеграфной,} \mathrm{телефонной} \mathrm{и} \mathrm{радиосвязи} \mathrm{Союза} \mathrm{ССР»} \mathrm{от} 15$ февраля 1929 г. (утратило силу в связи с постановлением Совета Министров СССР от 10 августа 1953 г. № 2122). URL: http://www.libussr.ru/ doc_ussr/ussr_3556.htm

6 Уголовный кодекс РСФСР. Постановление ВЦИК РСФСР «О введении в действие Уголовного Кодекса РСФСР редакции 1926 года» от 22 ноября 1926 г. (утратило силу с 1 января 1961 г. в связи с принятием Уголовного Кодекса РСФСР 1961 г.). URL: http://docs.cntd.ru/document/901757374

7 Логінов І.В. Умови настання кримінальної відповідальності за незаконне застосування технічних засобів для негласного отримання інформації. Теорія і практика юридичної відповідальності за правопорушення в інформачійній сфері : матеріали наук.-практ. конф. (м. Київ, 08 червня 2016 р.). Київ, 2016. С. 144.

8 Кримінальний кодекс України. Науково-практичний коментар: у 2 т. / заг. ред. Ю.В. Баулін, В.І. Борисов, В.І. Тютюгін та ін. Харків : Право, 2013. Т. 2: Особлива частина. С. 761.

9 Про право власності на окремі види майна: постанова Верховної Ради України від 17 червня 1992 р. № 2471-XII. Bidoмості Верховної Ради України. 1992. № 35. Ст. 517. URL: https://zakon.rada.gov.ua/laws/show/2471-12

10 Про затвердження Інструкції про умови і правила провадження підприємницької діяльності (ліцензійні умови) 3 розроблення, виготовлення і реалізації спеціальних технічних засобів (в тому числі іноземного виробництва) для зняття інформації з каналів зв'язку, інших засобів негласного отримання інформації та контроль за їх дотриманням: наказ Служби безпеки України від 07 квітня 1999 р. № 30/76 (втратив чинність). Офіційний вісник України. 1999. № 18. C. 145. URL: https://zakon. rada.gov.ua/laws/show/ru/z0275-99

11 Конституція України : Закон України від 28 червня 1996 р. № 254к/96-ВР. Відомості Верховної Ради Украӥни. 1996. № 30. Ст. 141. URL: https://zakon.rada.gov.ua/laws/show/254к/96-вр

12 Кримінальний кодекс України від 05 квітня 2001 р. № 2341-III. Відомості Верховної Ради України. 2001. № 25-26. Ст. 131. URL: https://zakon.rada.gov.ua/laws/show/2341-14 
13 Цивільний кодекс України від 16 січня 2003 р. № 435-IV. Відомості Верховної Ради України. 2003. № 40-44. Ст. 356. URL: https://zakon.rada.gov.ua/laws/show/435-15

14 Про впорядкування виготовлення, придбання та застосування технічних засобів для зняття інформації з каналів зв'язку: Указ Президента України від 13 квітня 2001 р. № 256/2001. Офіційний вісник Украӥни. 2001. № 16. Ст. 697. URL: https://zakon.rada.gov.ua/laws/show/256/2001

15 Про затвердження Ліцензійних умов провадження господарської діяльності з розроблення, виготовлення спеціальних технічних засобів для зняття інформації з каналів зв'язку, інших засобів негласного отримання інформації, торгівлі спеціальними технічними засобами для зняття інформації з каналів зв'язку, іншими засобами негласного отримання інформації : наказ Служби безпеки України та Державного комітету України з питань регуляторної політики та підприємництва від 29 січня 2001 р. № 17/17 (втратив чинність). Офіиійний вісник України. 2001. № 7. Ст. 289. URL: https://zakon.rada.gov.ua/laws/show/z0122-01

16 Про внесення змін до Кримінального кодексу України щодо відповідальності за незаконне поводження із спеціальними технічними засобами негласного отримання інформації: Закон України від 15 червня 2010 р. № 2338-VI. Biдомості Bepховної Ради України. 2010. № 32. Ст. 450. URL: https://zakon.rada.gov.ua/laws/show/2338-17

17 Пасєка О.Ф. Окремі проблемні аспекти кримінальної відповідальності за незаконне придбання, збут або використання спеціальних технічних засобів негласного отримання інформації за КК України. Науковий вісник Львівського державного університету внутрішніх справ. 2016. № 2. С. 303.

18 Про внесення змін до Кримінального кодексу України щодо відповідальності за незаконне поводження із спеціальними технічними засобами негласного отримання інформації: пояснювальна записка до проекту Закону України (реєстр. № 3358 від 12.11.08). URL: http://w1.c1.rada.gov.ua/pls/zweb2/webproc4_1?pf3511=33655

19 Про внесення змін до деяких законів України щодо розвідувальних органів України: Закон України від 19 березня 2015 р. № 267-VIII. Відомості Верховної Ради України. 2015. № 22. Ст. 151. URL: https://zakon.rada.gov.ua/laws/show/267-19

20 Деякі питання щодо спеціальних технічних засобів для зняття інформації з каналів зв’язку та інших технічних засобів негласного отримання інформації: постанова Кабінету Міністрів України від 22 вересня 2016 р. № 669. Офіиійний вісник України. 2016. № 79. Ст. 2640. URL: https://zakon.rada.gov.ua/laws/show/669-2016-п

21 Там само.

22 Про затвердження Ліцензійних умов провадження господарської діяльності з розроблення, виготовлення спеціальних технічних засобів для зняття інформації з каналів зв'язку, інших засобів негласного отримання інформації, торгівлі спеціальними технічними засобами для зняття інформації з каналів зв'язку, іншими засобами негласного отримання інформації: наказ Держкомпідприємництва та Служби безпеки України від 10 жовтня 2006 р. № 92/669 (втратив чинність. Офіиійний вісник України. 2006. № 44. Ст. 2967. URL: https://zakon.rada.gov.ua/laws/show/z1170-06

23 Про затвердження Ліцензійних умов провадження господарської діяльності з розроблення, виготовлення спеціальних технічних засобів для зняття інформації з каналів зв'язку, інших засобів негласного отримання інформації, торгівлі спеціальними технічними засобами для зняття інформації з каналів зв'язку, іншими засобами негласного отримання інформації та Порядку контролю за додержанням Ліцензійних умов: наказ Служби безпеки України від 31 січня 2011 р. № 35 (втратив чинність). Офіційний вісник України. 2011. № 16. Ст. 703. URL: https://zakon.rada.gov.ua/laws/show/z0225-11

\section{References:}

Voznyj, V. I. Heneza zakonodavstva pro vidpovidal'nist' u sferi spetsial'nykh tekhnichnykh zasobiv nehlasnoho otrymannia informatsii. Modern directions of theoretical and applied researches 2013. SWorld (19-30 March 2013). URL:http://www.sworld. com. ua/ sindex.php/ru/conference/the-content-of-conferences/archives-of-individual-conferences/march-2013 [in Ukrainian].

Deklaratsiia pro derzhavnyj suverenitet vid 16 lypnia 1990 r. № 55-KhII. (1990) Vidomosti Verkhovnoi Rady URSR. $31,429$. URL: https://zakon.rada.gov.ua/laws/show/55-12 [in Ukrainian].

Tymchenko, L. D. (2012) Mizhnarodne pravo : pidruchnyk. Kyiv : Znannia [in Ukrainian].

Tsymbal, M.I. (2011) Inozemnyj dosvid kryminal'no-pravovoi protydii nezakonnoho povodzhennia iz spetsial'nymy tekhnichnymy zasobamy nehlasnoho otrymannia informatsii. Naukovyj visnyk Akademii munitsypal'noho upravlinnia. Seriia «Pravo». 232 [in Ukrainian].

Ustav pochtovoj, telehrafnoj, telefonnoj y radyosviazy Soiuza SSR. Postanovlenye Soveta Narodnykh komyssarov SSSR «O vvedenyy v dejstvye Ustava pochtovoj, telehrafnoj, telefonnoj y radyosviazy Soiuza SSR» ot 15 fevralia 1929 h. (utratylo sylu v sviazy s postanovlenyem Soveta Mynystrov SSSR ot 10 avhusta 1953 h. № 2122). URL: http://www.libussr.ru/doc_ussr/ussr_3556.htm [in Russian].

Uholovnyj kodeks RSFSR. Postanovlenye VTsYK RSFSR «O vvedenyy v dejstvye Uholovnoho Kodeksa RSFSR redaktsyy 1926 hoda» ot 22 noiabria 1926 h. (utratylo sylu s 1 ianvaria 1961 h. v sviazy s pryniatyem Uholovnoho Kodeksa RSFSR 1961 h.). URL: http://docs.cntd.ru/document/901757374 [in Russian].

Lohinov, I. V. (2016) Umovy nastannia kryminal'noi vidpovidal'nosti za nezakonne zastosuvannia tekhnichnykh zasobiv dlia nehlasnoho otrymannia informatsii. Teoriia i praktyka iurydychnoi vidpovidal'nosti za pravoporushennia $\mathrm{v}$ informatsijnij sferi : materialy nauk.-prakt. konf. (m. Kyiv, 08 chervnia 2016 r.). Kyiv, 144 [in Ukrainian].

Baulin, Yu. V., Borysov, V. I., Tiutiuhin, V. I. ta in. (za zag. red.). (2013). Kryminal'nyj kodeks Ukrainy. Naukovo-praktychnyj komentar: u 2 t. Kharkiv : Pravo, T. 2: Osoblyva chastyna [in Ukrainian].

Pro pravo vlasnosti na okremi vydy majna: postanova Verkhovnoi Rady Ukrainy vid 17 chervnia 1992 r. № 2471-XII. (1992) Vidomosti Verkhovnoi Rady Ukrainy. 35, 517. URL: https://zakon.rada.gov.ua/laws/show/2471-12 [in Ukrainian].

Pro zatverdzhennia Instruktsii pro umovy i pravyla provadzhennia pidpryiemnyts'koi diial'nosti (litsenzijni umovy) z rozroblennia, vyhotovlennia i realizatsii spetsial'nykh tekhnichnykh zasobiv (v tomu chysli inozemnoho vyrobnytstva) dlia zniattia informatsii z kanaliv zv'iazku, inshykh zasobiv nehlasnoho otrymannia informatsii ta kontrol' za ikh dotrymanniam: nakaz Sluzhby bezpeky Ukrainy vid 07 kvitnia 1999 r. № 30/76 (vtratyv chynnist'). (1999) Ofitsijnyj visnyk Ukrainy. 18, 145. URL: https://zakon.rada.gov.ua/laws/ show/ru/z0275-99 [in Ukrainian].

Konstytutsiia Ukrainy : Zakon Ukrainy vid 28 chervnia 1996 r. № 254k/96-VR. (1996) Vidomosti Verkhovnoi Rady Ukrainy. 30, 141. URL: https://zakon.rada.gov.ua/laws/show/254k/96-vr [in Ukrainian].

Kryminal’nyj kodeks Ukrainy vid 05 kvitnia 2001 r. № 2341-III. (2001). Vidomosti Verkhovnoi Rady Ukrainy. 25-26, 131. URL: https://zakon.rada.gov.ua/laws/show/2341-14 [in Ukrainian]. 
Tsyvil'nyj kodeks Ukrainy vid 16 sichnia 2003 r. № 435-IV. (2003). Vidomosti Verkhovnoi Rady Ukrainy. 40-44, 356. URL: https://zakon.rada.gov.ua/laws/show/435-15 [in Ukrainian].

Pro vporiadkuvannia vyhotovlennia, prydbannia ta zastosuvannia tekhnichnykh zasobiv dlia zniattia informatsii z kanaliv zv'iazku: Ukaz Prezydenta Ukrainy vid 13 kvitnia 2001 r. № 256/2001. (2001) Ofitsijnyj visnyk Ukrainy. 16, 697. URL: https://zakon.rada. gov.ua/laws/show/256/2001 [in Ukrainian].

Pro zatverdzhennia Litsenzijnykh umov provadzhennia hospodars'koi diial'nosti z rozroblennia, vyhotovlennia spetsial'nykh tekhnichnykh zasobiv dlia zniattia informatsii z kanaliv zv'iazku, inshykh zasobiv nehlasnoho otrymannia informatsii, torhivli spetsial'nymy tekhnichnymy zasobamy dlia zniattia informatsii z kanaliv zv'iazku, inshymy zasobamy nehlasnoho otrymannia informatsii : nakaz Sluzhby bezpeky Ukrainy ta Derzhavnoho komitetu Ukrainy z pytan' rehuliatornoi polityky ta pidpryiemnytstva vid 29 sichnia 2001 r. № 17/17 (vtratyv chynnist'). (2001) Ofitsijnyj visnyk Ukrainy. 7, 289. URL: https://zakon.rada.gov.ua/laws/show/z0122-01 [in Ukrainian].

Pro vnesennia zmin do Kryminal'noho kodeksu Ukrainy schodo vidpovidal'nosti za nezakonne povodzhennia iz spetsial'nymy tekhnichnymy zasobamy nehlasnoho otrymannia informatsii: Zakon Ukrainy vid 15 chervnia 2010 r. № 2338-VI. (2010). Vidomosti Verkhovnoi Rady Ukrainy. 32, 450. URL: https://zakon.rada.gov.ua/laws/show/2338-17 [in Ukrainian].

Pasieka, O.F. (2016) Okremi problemni aspekty kryminal'noi vidpovidal'nosti za nezakonne prydbannia, zbut abo vykorystannia spetsial'nykh tekhnichnykh zasobiv nehlasnoho otrymannia informatsii za KK Ukrainy. Naukovyj visnyk L'vivs'koho derzhavnoho universytetu vnutrishnikh sprav. 2, 303 [in Ukrainian].

Pro vnesennia zmin do Kryminal'noho kodeksu Ukrainy schodo vidpovidal'nosti za nezakonne povodzhennia iz spetsial'nymy tekhnichnymy zasobamy nehlasnoho otrymannia informatsii: poiasniuval'na zapyska do proektu Zakonu Ukrainy (reiestr. № 3358 vid 12.11.08). URL: http://w1.c1.rada.gov.ua/pls/zweb2/webproc4 1?pf3511=33655 [in Ukrainian].

Pro vnesennia zmin do deiakykh zakoniv Ukrainy schodo rozviduval'nykh orhaniv Ukrainy: Zakon Ukrainy vid 19 bereznia 2015 r. № 267-VIII. (2015). Vidomosti Verkhovnoi Rady Ukrainy. 22, 151. URL: https://zakon.rada.gov.ua/laws/show/267-19 [in Ukrainian].

Deiaki pytannia schodo spetsial'nykh tekhnichnykh zasobiv dlia zniattia informatsii z kanaliv zv'iazku ta inshykh tekhnichnykh zasobiv nehlasnoho otrymannia informatsii: postanova Kabinetu Ministriv Ukrainy vid 22 veresnia 2016 r. № 669. (2016). Ofitsijnyj visnyk Ukrainy. 79, 2640. URL: https://zakon.rada.gov.ua/laws/show/669-2016-p [in Ukrainian].

Pro zatverdzhennia Litsenzijnykh umov provadzhennia hospodars'koi diial'nosti z rozroblennia, vyhotovlennia spetsial'nykh tekhnichnykh zasobiv dlia zniattia informatsii z kanaliv zv'iazku, inshykh zasobiv nehlasnoho otrymannia informatsii, torhivli spetsial'nymy tekhnichnymy zasobamy dlia zniattia informatsii z kanaliv zv'iazku, inshymy zasobamy nehlasnoho otrymannia informatsii: nakaz Derzhkompidpryiemnytstva ta Sluzhby bezpeky Ukrainy vid 10 zhovtnia 2006 r. № 92/669 (vtratyv chynnist'). (2006). Ofitsijnyj visnyk Ukrainy. 44, 2967. URL: https://zakon.rada.gov.ua/laws/show/z1170-06 [in Ukrainian].

Pro zatverdzhennia Litsenzijnykh umov provadzhennia hospodars'koi diial'nosti z rozroblennia, vyhotovlennia spetsial'nykh tekhnichnykh zasobiv dlia zniattia informatsii z kanaliv zv'iazku, inshykh zasobiv nehlasnoho otrymannia informatsii, torhivli spetsial'nymy tekhnichnymy zasobamy dlia zniattia informatsii z kanaliv zv'iazku, inshymy zasobamy nehlasnoho otrymannia informatsii ta Poriadku kontroliu za doderzhanniam Litsenzijnykh umov: nakaz Sluzhby bezpeky Ukrainy vid 31 sichnia 2011 r. № 35 (vtratyv chynnist'). (2011). Ofitsijnyj visnyk Ukrainy. № 16, 703. URL: https://zakon.rada.gov.ua/laws/show/z0225-11 [in Ukrainian].

\section{Резюме}

Хлопов А.О. Тенденції розвитку законодавства у сфері кримінально-правового регулювання застосування та обігу спеціальних технічних засобів негласного отримання інформації.

У статті представлено аналіз формування та розвитку нормативно-правової бази у сфері застосування та обігу спеціальних технічних засобів негласного отримання інформації у розрізі етапів розвитку правової думки. Обгрунтовується потреба перегляду окремих нормативно-правових актів для досягнення узгодженості між ними та створення передумов для виконання покладених на них функцій із захисту прав і свобод людини в інформаційному вимірі. Оголошено запит на осучаснення та модернізацію джерел права з метою покращення інвестиційного клімату, розвитку науково-технічного прогресу, суспільних відносин та адаптації вітчизняного законодавства до законодавства Європейського Союзу.

Ключові слова: спеціальні технічні засоби негласного отримання інформації, негласне отримання інформації, кримінальне законодавство, законодавча база, нормативно-правове забезпечення.

\section{Резюме}

Хлопов А.А. Тенденции развития законодательства в сфере уголовно-правового регулирования применения и оборота специальных технических средств негласного получения информации.

В статье представлен анализ формирования и развития нормативно-правовой базы в сфере обращения со специальными техническими средствами негласного получения информации в разрезе этапов развития правовой мысли. Обосновывается необходимость пересмотра отдельных нормативно-правовых актов для достижения согласованности между ними и создания предпосылок для выполнения возложенных на них функций по защите прав и свобод человека в информационном измерении. Объявлен запрос на осовременивание и модернизацию источников права с целью улучшения инвестиционного климата, развития научно-технического прогресса, общественных отношений и адаптации отечественного законодательства к законодательству Европейского Союза.

Ключевые слова: специальные технические средства негласного получения информации, специальные технические средства, криминальное законодательство, законодательная база, нормативно-правовое обеспечение.

\section{Summary}

Artem Khlopov. The trends of development of legislation in the field of criminal and legal regulation application and training of special technical means of private getting of information.

The development of scientific and technological progress has led to new challenges and has called for the settlement of new spheres of human life. Access to the Ukrainian markets of means that can secretly record, process and transmit information about a per- 
son without his consent led to the introduction of article 359 in the Criminal Code of Ukraine in 2001, which was intended to protect the human right to confidentiality of information about himself and his relatives and to establish an exclusive the right to use these funds for the authorized authorities of the state.

It should be noted that the issue of developing legislation in the area of dealing with special technical means of clandestine information was almost not carried out, and separately studied issues only partially identified some points, without tracing the chronology of the trends of criminal law regulation in this area at different stages of development.

The article is almost the first time the legislative layer of acts in the area of handling of special technical means of private getting of information, which is divided into three stages. In the analysis of the main sources of law, progressive approaches to the formation of the legislative framework and unfinished steps that indicate the inconsistent introduction of changes and additions, and sometimes the lack of understanding by the legislator of technical points, which does not add to legal certainty, as a consequence of which there is a lack of understanding by ordinary citizens, which acts are criminally punishable.

This article reveals the most acute problems existing in the legislative sources, allows us to take a fresh look at some issues of legal regulation. Moreover, it raises issues that have not been studied in practice at all, while providing recommendations for improving legislation, both conceptually and at the regulatory level. Much attention is paid to the continuous updating of licensing conditions for the management of economic activity with special technical means of private getting of information, which not only creates pressure on entrepreneurship due to constant updating of the rules, but also complicates the access of high technologies to the domestic markets of Ukraine.

In concluding the above-mentioned, there is an urgent need to modernize the legislative framework by reviewing the changes already made and their additions to modern realities of social relations and acts of a higher level, and in view of the expansion of the use of special means and their types - to identify generic features, hierarchical structure, classification and to provide a conclusion on the ratio of all types of special means within the concept of "special technical means getting of information", the so-called STM, in accordance with art. 359 of the Criminal Code of Ukraine.

Key words: special technical means of private getting of information, special technical means, criminal law, legislative base, regulatory framework.

DOI: $10.36695 / 2219-5521.2 .2019 .35$

УДК 343.85

\section{К.В. ШЕЙКО}

Костянтин Володимирович Шейко, здобувач Національного юридичного університету імені Ярослава Мудрого*

ORCID: 0000-0001-6193-3443

\section{МІЖНАРОДНИЙ ДОСВІД ПРОТИДІЇ НЕЗАКОННОМУ ОБІГУ АЛКОГОЛЬНИХ НАПОЇВ}

Постановка проблеми. Проблема незаконного виробництва та обігу алкогольної продукції притаманна не тільки Україні, а й майже всім країнам світу. У деяких державах вдалося владі та суспільству взяти під контроль цей нелегальний сегмент економіки та звести його до мінімальних обсягів. Саме досвід цих країн стане для України позитивним прикладом протидії такому негативному явищу.

Формулювання мети статті. Метою статті $є$ аналіз досвіду протидії незаконному обігу алкогольних напоїв в країнах Північної Америки, Свропи та Туреччини. Зроблені висновки можуть бути покладені в основу формування державної політики у сфері запобігання незаконному виробництву та обігу алкогольних напоїв в Україні.

Виклад основного матеріалу. В розвинутих країнах світу формування державою ринку алкогольної продукції має значний вплив на сфери виробництва, розподілу та споживання алкогольних напоїв, а тому потребує посиленого та всебічного контролю. Різні методи та способи контролю за обігом алкогольних товарів у різних країнах проходили свій шлях розвитку, виявляючи позитивні чи негативні результати. Узагальнивши їх, можна виділити основні напрями протидії незаконному обігу алкогольних напоїв, зокрема, це: встановлення державної монополії, ліцензування, державне та приватне партнерство, ринкова модель. Для ефективної протидії як легальному, так і нелегальному обігу алкогольних напоїв необхідне поєднання усіх цих способів контролю в державі.

Особливістю зарубіжного регулювання вказаної галузі економіки є реалізація збалансованої концепції розвитку ринку алкогольної продукції із залученням центру, регіонів та бізнес-товариств. Зазначена політика закріплена на законодавчому рівні країн Північної Америки. Необхідно звернути увагу, що бізнес в галузі виготовлення та реалізації алкогольних напоїв у зарубіжних країнах має консолідований характер. Це підтверджує діяльність великої кількості національних, міжрегіональних та міжнародних об'єднань, асоціацій та союзів виробників, дистриб'юторів і реалізаторів алкогольної продукції. Наведені професійні об'єднання

(c) К.В. Шейко, 2019

${ }^{*}$ Kostiantyn Sheiko, postgraduate student of Yaroslav Mudryi National Law University 